
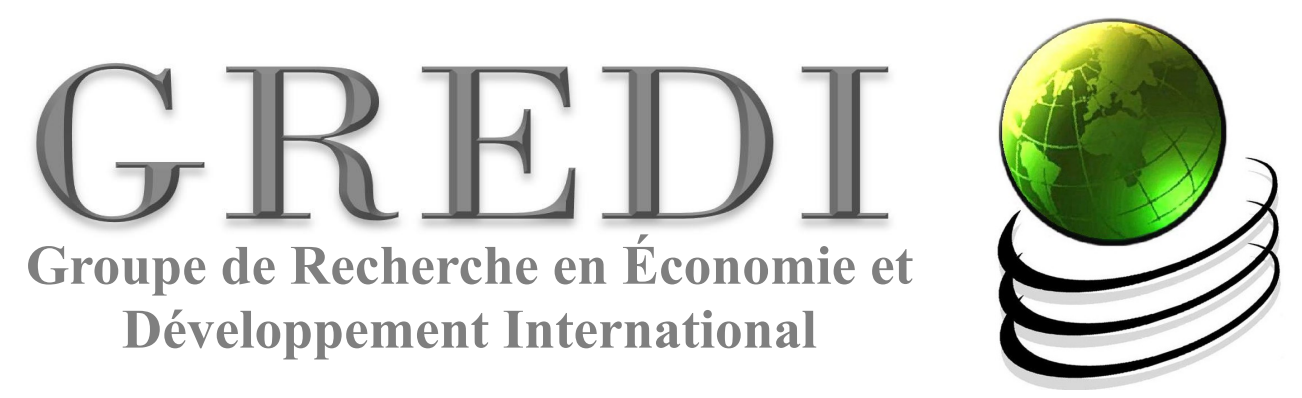

Cahier de Recherche / Working Paper

12-12

Households' living situation and the efficient provision of primary education in Burkina Faso

\author{
Élisé Wendlassida Miningou
}

Valérie Vierstraete 


\title{
Households' living situation and the efficient provision of primary education in Burkina Faso
}

\author{
Élisé Wendlassida Miningou*, Valérie Vierstraete ${ }^{\dagger}$
}

September 14, 2012

\begin{abstract}
Primary education plays a central role in the Burkinabe school system. Several projects have been launched that contribute to expanding the resources available for basic education in Burkina Faso. However, education systems in the different administrative regions of Burkina Faso may not all be equally capable of employing the resources they receive to generate significant results. This study uses the data envelopment analysis (DEA) method to assess the efficiency with which basic education is provided throughout the 45 provinces of Burkina Faso. Overall, our results reveal that resources are not used optimally for the provision of basic education in the provinces of Burkina Faso. Moreover, in most of the provinces studied, returns to scale in basic education are decreasing. In order to explain inefficiency scores, we also use the Simar and Wilson (2007) procedure. We find that households' living situation can explain efficiency in primary education provision.
\end{abstract}

Keywords: Data Envelopment Analysis, Efficiency, Primary education, Burkina Faso, Bootstrap procedures

\section{Introduction}

In most countries, primary education is considered the first step in educating the population. The principal role played by primary education is therefore to provide individuals with the skills required to prepare them for the higher levels. This isn't exactly the situation in many sub-African countries. In these countries, one of the key objectives of primary education is to actively participate in the human development of the population by providing them with the opportunity to learn to read and write. Primary education is thus principally

\footnotetext{
*Economic Department, University of Sherbrooke, 2500, boulevard de l'Université Sherbrooke (Québec) J1K 2R1,CANADA

${ }^{\dagger}$ Economic Department, University of Sherbrooke, 2500, boulevard de l'Université Sherbrooke (Québec) J1K 2R1,CANADA; Valerie.Vierstraete@usherbrooke.ca
} 
designed to combat illiteracy. With help from development partners (World Bank, UNESCO, etc), some African government has taken steps to render primary school education accessible to the entire population. Since the World Conference on Education for All in 1990 in Jontiem to the Millennium Development Goals adopted in 2000, numerous projects have thus been launched to assist the development of basic education. Overall, since 2000, the resources devoted to primary education in many Sub-African countries have received a significant boost. However, very frequently the distribution of these resources is driven by political considerations. Provinces or regions in which decision makers have much at stake are often given preferential treatment over the others ${ }^{1}$. This situation could result in waste. Also, it is possible that the education systems in various regions in a country are not all equally able to employ the resources provided to them to generate appreciable results. For example, two regions having access to the same resources may not produce the same results in terms of educating the population. It thus appears worthwhile to assess the efficiency with which resources are used in basic education. This could, subsequently, allow explanatory factors for this efficiency to be identified.

In 2002 began in Burkina Faso the Programme Décennal de Développement de l'Éducation de Base (PDDEB) (Ten-year Basic Education Development Plan), which was set up by the Burkinabe government and its development partners, in order to promote access and quality of the education for children aged three to 12 years. Ten years later, the results are uneven within the country. Disparities exist between Burkinabe provinces and within every province. With a public sector suffering from resources limitations and many civil society organizations involved, efficiency of the Burkinabe educational system could thus be addressed to identify the potential sources of waste. This is the main purpose of our research. For it, our study first examines the issue of efficiency in primary education by assessing the success of Burkina Faso's 45 provinces in reaching their goals in terms of the quality of, and access to, education. We next propose factors to explain efficiency in resource allocation in education. The remainder of this paper begins with a presentation of primary education in Burkina Faso, followed by a review of the literature on measuring efficiency in education. In a fourth section we discuss our methodology, and the fifth section presents the data. Next, a presentation and analysis of the results of the study is followed by a conclusion.

\section{Primary education in Burkina Faso}

Located in West Africa, Burkina Faso is one of the poorest countries in the world. Ranked 177th on the Human Development Index (HDI), the population of Burkina Faso is among the least educated in the world. In order to improve the efficiency of efforts to educate the population, management structures for

\footnotetext{
${ }^{1}$ Generally, these are the home provinces/ regions of the individuals in power, where their political power bases are usually concentrated.
} 
primary education have been decentralized at the level of the 45 provinces and 13 regions. In this vein, the government of Burkina Faso has had an education policy Perspectives de développement du système éducatif à l'horizon de l'année 2010 (Development prospects for the education system until 2010) in place since 1994. This policy has two principal objectives: first, to expand access to basic education with a view to universality while improving its quality and, second, to develop the education system, including the post-primary levels, in order to meet the demand for skilled labour and to ensure that graduates meet the needs of the economy in terms of quality and quantity. Therefore, basic education has assumed a pivotal role in the country's development policies. The Cadre stratégique de lutte contre la pauvreté (Poverty Reduction Strategy Paper), Burkina Faso's flagship development policy paper, assigns a central role to education. Furthermore, as of its inception, the PDDEB has envisioned mobilizing over 235 billion CFA francs (approximately \$CAN600 million), primarily for building classrooms, training educators, and equipping the basic education sector in the different provinces of Burkina Faso. The principal objectives of the PDDEB were to raise the school attendance rate to $70 \%$ by 2010 , to improve the quality, relevance, and efficiency of basic education, to increase the literacy rate to $40 \%$, and to develop skills in leadership, management, and the evaluation of structures (Ministère de l'économie et des finances, 2004). Access to basic education has progressed well since the PDDEB was launched in the 2000s. The gross rate of school attendance rose from $44.7 \%$ in 2000 to $72.4 \%$ in 2009. The gross rate of admissions into first grade rose from $45.4 \%$ in 2000 to $78 \%$ in 2009. Quality indicators also appear to have improved. Thus, the rate at which primary school leaving certificates were earned rose from $49.1 \%$ in 2000 to $72.7 \%$ in 2009 . The primary school completion rate rose from $26.2 \%$ in 2000 to $41.7 \%$ in $2009^{2}$. However, these positive developments in educational indicators conceal disparities between the regions. For example, in 2008, while the gross school attendance rate was $54 \%$ in the Eastern Region, it was $102.7 \%^{3}$ in the Central region. Moreover, in 2008 the primary school leaving certificate obtention rate was $71.9 \%$ in the Central-North region, but only $49.8 \%$ in the Central-South region. A question can arise from these mere figures. Can result differences be only due to differences of resources but also to differences of the efficiency in the use of resources? Thus, it appears important to identify the relationship between resources devoted to primary education and the results obtained in each province of Burkina Faso. Are there provinces that are using "more" resources than required in comparison with other provinces? Or, in other words, are there provinces that are inefficient?

\footnotetext{
${ }^{2}$ Cf. Institut National de la Statistique et de la Démographie (INSD) http://www.insd.bf/fr/

${ }^{3}$ This value reflects the possibility that children below or above the normal age were attending school.
} 


\section{$3 \quad$ Measuring efficiency in education}

The literature on measuring efficiency in education contains two types of methods: parametric and nonparametric. Of the parametric efficiency measures, stochastic frontier analysis (SFA) and deterministic frontier analysis methods have been most widely used by researchers in this field. For example, Barrow (1991) uses the deterministic frontier method to estimate the performance of school boards in Great Britain. He demonstrates that the cost of education is positively correlated with students being from a socioeconomically disadvantaged background, the free distribution of meals, and the need for students to have supplementary knowledge. Using the stochastic frontier, Deller and Rudnicki (1993) identify parents' education levels and the unemployment rate as explanatory factors for inefficiency in education. Among nonparametric approaches, data envelopment analysis (DEA) is most frequently used to measure efficiency in education. According to Worthington (2001), Bessent et al. (1982) pioneered the use of DEA in education. These authors use a DEA model to assess the efficiency of 241 school districts in the city of Houston in the United States. They evaluate the impact of the type of financing received and teachers' level of experience and qualifications on the efficiency of these districts. Several other authors have used the DEA method to examine efficiency in education. These include, notably, Färe et al. (1989) in their study of the performance of school districts in Missouri, Ray (1991) for schools in Connecticut, Thanassoulis and Dunstan (1994) and Bates (1997) for school boards in Great Britain, Ruggiero (1996), Engert (1996) and Duncombe et al. (1997) for the efficiency of school districts in New York state, and Chalos (1997) for the efficiency of school districts in the state of Illinois.

The DEA method has often been used in conjunction with other methods to measure efficiency in education. For example, Johnes (2003) employs a DEA model and a multilevel model to study the efficiency of English universities and demonstrates that, when individual students' levels of effort are removed, the efficiency results of these institutions appear to be equal regardless of the method. Afonso and St. Aubyn (2006) use a DEA model and a Tobit estimated

with the bootstrap method to evaluate the efficiency of educational systems of 25 countries in the OECD. They find that efficiency depends on per-capita GDP and adults' education levels.

\section{Methodology}

As previously discussed, there are two primary approaches to measuring efficiency: parametric and nonparametric methods. Since parametric models generally require assumptions on functional forms, we will opt for a nonparametric method in this study (the DEA model). This nonparametric method has the benefit of requiring less constraining assumptions than most parametric methods. 
DEA is a nonparametric method derived from the Farrell (1957) model of technical and allocative efficiency. It is based on an interior approximation to the production technology of decision-making units (DMU) and requires two major assumptions: free disposal and convex combinations. These two assumptions allow an empirical production frontier to be constructed and the inefficiency of each DMU to be assessed in terms of its position relative to that frontier vertically (output orientation) and horizontally (input orientation). The most commonly used underlying models are the CCR (Charnes, Cooper and Rhodes, 1978) and BCC (Banker, Charnes and Cooper, 1984). In our study, we use an output-oriented CCR model. Our choice of CCR model is essentially attributable to the fact that it allows us to examine returns to scale in primary education in Burkina Faso. Furthermore, the output orientation reveals the increase in output that would be required for a given DMU to be efficient, whereas the input orientation reveals by how much inputs can be reduced, for a given output, for the DMU to be considered efficient. We believe that this orientation reflects the objectives of the Burkinabe authorities, who appear to favour a policy of increasing educational outputs rather than one of decreasing inputs. If $y_{m, n}$, and $x_{r, n}$, are $M$ outputs and $R$ inputs, respectively, while $N$ indicates the number of DMUs in the sample, analytically the CCR model in the output orientation looks as follows:

$$
\begin{gathered}
\operatorname{Max}\left[\delta+\varepsilon \sum S_{m}^{+}+\epsilon \sum S_{r}^{-}\right] \\
\sum \lambda_{n} y_{m, n} \geq \delta y_{m, 0} \\
\sum \lambda_{n} x_{r, n} \geq x_{r, 0} \\
n=1, \ldots, N
\end{gathered}
$$

If $\sum \lambda_{n}>1 \quad \mathrm{DMU}_{n}$ is characterized by decreasing returns to scale; by constant returns to scale if $\sum \lambda_{n}=1$, and by increasing returns to scale if $\sum \lambda_{n}<1^{4}$

$\delta$ is the coefficient by which output must be multiplied for the DMU to be considered efficient; i.e., the efficiency score. $\mathrm{S}^{+}$and $\mathrm{S}^{-}$are slack variables allowing inequalities in (1) and (2) being converting in equalities. $\varepsilon$ is a nonArchimedian element allowing the system to be solved in two steps, first on $\phi$ and second on the slack variables. Constraints (1) and (2) allow the production frontier to be constructed thanks to $\lambda_{n}$ a weighting coefficient.

\footnotetext{
${ }^{4}$ Cf. Cooper, Seiford and Tone (2007)
} 
The DEA method is of particular relevance to our study because, unlike most econometric methods, it is compatible with multiple educational outputs and inputs. However, Simard and Wilson (1998) point out that the efficiency scores generated by the DEA method are biased. They propose a bootstrap technique allowing the bias of the efficiency scores to be estimated, so that scores calculated using the DEA method can be adjusted to correct for this bias. According to these authors, the bias associated with the efficiency score of each decision-making unit is given by Equation (3).

$$
\overline{B a i s}=B^{-1} \sum_{b=1}^{B} \widehat{\delta}_{b}^{*}-\widehat{\delta}
$$

$\widehat{\delta}_{b}^{*}$ is the efficiency score for sample $b$ calculated by the DEA method. $B$ is the total number of simulations and $\widehat{\delta}$ the estimate of of $\delta$. The efficiency score corrected for the bias is obtained from Equation (4).

$$
\widehat{\widehat{\delta}}=\widehat{\delta}-\overline{\text { Bais }}=2 \widehat{\delta}-B^{-1} \sum_{b=1}^{B} \delta_{b}^{*}
$$

However, Simar and Wilson (2008) point out that the bias correction obtained withEquation (4) introduces additional "noise". So if the ratio of the estimated bias and thevariance satisfies some conditions the unbiased efficiency score will be valid. Otherwise, efficiency scores obtained with the bootstrap method must be considered. Let $\widehat{\sigma}$ be an estimate of the variance of efficiency scores obtained from all bootstrap samples and forall DMUs.

$$
\sigma^{2}=B^{-1} \sum_{b=1}^{B}\left[\widehat{\delta}_{b}^{*}-B^{-1} \sum_{b=1}^{B} \widehat{\delta}_{b}^{*}\right]^{2}
$$

For these unbiased efficiency scores to be valid, each of them must satisfy the following condition:

$$
\frac{\overline{\mid \text { Bais }_{n} \mid}}{\widehat{\sigma}_{n}} \geq \frac{1}{\sqrt{3}}
$$

For our study we use panel data covering eight years. This allows us to evaluate efficiency for each year and for each province. In order to allow intertemporal comparisons of a single DMU while also increasing the precision with which efficiency scores are calculated we adopt the window analysis approach, which consists of treating each province each year as a decision-making unit in its own right.

The DEA method has a number of benefits, but it also suffers from certain drawbacks. Among others, we note that this method treats all deviations from the production frontier as inefficiencies, including those attributable to measurement error. The bootstrap method allows this to be addressed to some extent, 
but DEA remains a deterministic method. One solution to this problem would be to use a stochastic frontier model. However, as we have already shown, the DEA method is preferable to the SFA method because it can accommodate several outputs. Since the purpose of our study is to evaluate the efficiency with which resources are used to improve not only access to, but also the quality of, education, we will have to define at least two outputs. Consequently, the DEA method proves to be the best suited to our analytical requirements.

The DEA method has been used in several studies on Burkina Faso. For example, Marschall and Flessa (2009) use it to demonstrate that rural healthcare centres in Burkina Faso are inefficient from the perspective of scale. Wouterse (2011) evaluates the efficiency of the Burkinabe agricultural sector. She finds that access to education has a positive impact on efficiency in Burkina Faso's agricultural sector. To the best of our knowledge, the DEA method has not yet been applied to an assessment of the efficiency of Burkina Faso's education sector.

Another objective of our study is to examine the factors that might explain efficiency in the primary education system in the 45 provinces of Burkina Faso. The literature contains several econometric tools for analysing the impact of environmental variables on efficiency scores yielded by the DEA method. For example, some authors employ ordinary least squares to regress DEA efficiency scores on a set of explanatory variables (for example, Sexton et al., 1994; Stanton, 2002), while others perform econometric regressions using models such as Tobit (for example, Kumar and Gulati, 2009 and Guihong, 2010). In order to reflect the fact that the DEA scores are bounded, some authors use logarithmic, logistic, or log-normal transformations (for example, Ray, 1991; PuigJunoy, 1998). However, according to Simar and Wilson (2007), the validity of results yielded by these methods is debatable owing to the general absence of any discussion of the data generating process (DGP) of efficiency scores from the DEA. These authors present a discussion of the efficiency score DGP for the DEA method and propose estimation algorithms based on the bootstrap method. These algorithms allow biased parameter estimates for the explanatory variables of the efficiency scores to be corrected and provide for appropriate statistical inference. The two algorithms (1 and 2) by Simar and Wilson (2007) are equivalent for large samples, but algorithm 2 is more reliable for small samples. In light of the size of our sample, we opted for the second Simar and Wilson (2007) algorithm ${ }^{5}$.

The Simar and Wilson (2007) method has seen several empirical applications in the economics of education. For example, Bourdon (2009) employs this method to evaluating the efficiency of the PASEC program in Guinea. Also, Alexander, Haug, and Jaforullah, (2010) use it to measure the efficiency of secondary schools in New Zealand. Parteka and Wolszczak-Derlacz (2011) evaluate the efficiency of the education system in seven European countries with this method.

\footnotetext{
${ }^{5}$ Cf. Simar and Wilson (2007) for the details of the algorithm used.
} 


\section{Data}

The territorial organization of the primary education system in Burkina Faso corresponds with the nation's administrative boundaries. Elementary schools are organized into provincial primary education boards, and these provincial boards, in turn, into regional boards. These provincial and regional boards are responsible for providing guidance, management, educational and professional assessments, and planning. All the data we use are from Burkina Faso's Ministère des Enseignements de Base et de l'Alphabétisation (MEBA, Ministry of Basic Education and Literacy) and from Burkina Faso's Institut National de la Statistique et de la Démographie (INSD, National Institute of Statistics and Demographics). MEBA data relate to basic education in the 45 Burkinabe provinces and cover the school years 2003-2004 to 2010-2011. Data from INSD cover the years 2003, 2005, and 2007 at the regional level. Consequently, our only option is to assign data from the corresponding region to each province. To apply the DEA method we need to define inputs and outputs. In other words, the factors of production and the product of education need to be identified. According to Michaud (1981), this exercise is particularly challenging in the case of education because there are numerous objectives and the means to attain them are difficult to isolate. Nonetheless, in the literature some authors have attempted to provide descriptions of the inputs and outputs of education. For example, Schultz (1961) and Becker (1964) define the product of education in terms of higher personal incomes earned by the more educated. Denison (1962) suggests that the contribution education makes to domestic economic growth provides a measure of the product of education. With regard to the inputs to education, Burkhead (1967) proposes four broad categories of factors of production, to wit, the student's time, the staff's time, educational supplies, and buildings and equipment. Correa (1963), in turn, considers the assets and staff whose services are employed in the education process as factors of production in education. Our choice of inputs and outputs will essentially be based on the literature and our knowledge of the Burkinabe education system. According to the document Perspectives de développement du système éducatif à l'horizon de l'année 2010 (Development prospects for the education system until 2010), which lays the groundwork for Burkina Faso's primary education policy, the main goal is access to education and an improvement in the quality of education. Consequently, our choice of output should reflect these objectives. This leads us to retain two outputs: one measures the "quantity" of education, i.e. the gross school attendance rate, and the other the "quality" of education, i.e. the primary school completion rate. As to the inputs to education, we base our approach on concepts developed by Correa (1963) and Burkhead (1967). However, the purpose of our study being to evaluate the performance of administrative structures, we have omitted the pupils' and the staff's time: the former because it falls outside of the purview of educational bureaucracies and the latter because of the absence of data on hours worked. Following Correa (1963) and Burkhead (1967), inputs may be grouped into two categories, physical assets and human resources. Human resources that are directly involved 
in primary education in Burkina Faso are, in descending order of their level of qualification, principal teachers, certified teachers, certified assistant teachers, and assistant teachers. Lacking data on the number of assistant teachers, we have only retained values for the first three kinds of teachers (principal, certified, and certified assistant ones). As to inputs in the form of physical assets, we consider infrastructures (the number of classrooms per 100 pupils ${ }^{6}$ ) and instructional materials (the number of readers and arithmetic exercise books per student $)^{7}$.

\begin{tabular}{|c|c|c|c|c|c|}
\hline & $\begin{array}{c}\text { Number of } \\
\text { DMU }\end{array}$ & Minimum & Maximum & Mean & $\begin{array}{l}\text { Standard } \\
\text { deviation }\end{array}$ \\
\hline \multicolumn{6}{|l|}{ Inputs } \\
\hline Number of reader books/student & 360 & 0.210 & 1.700 & 0.869 & 0.330 \\
\hline $\begin{array}{l}\text { Number of arithmetic exercise books/ } \\
\text { student }\end{array}$ & 360 & 0.080 & 1.000 & 0.512 & 0.204 \\
\hline Number of principal teachers /100 pupils & 360 & 0.330 & 2.070 & 0.685 & 0.256 \\
\hline Number of certified teachers /100 pupils & 360 & 0.050 & 1.640 & 0.702 & 0.317 \\
\hline $\begin{array}{l}\text { Number of certified assistant teachers } / 100 \\
\text { pupils }\end{array}$ & 360 & 0.220 & 3.570 & 1.203 & 0.529 \\
\hline Number of classrooms/ 100 pupils & 360 & 1.420 & 4.600 & 2.023 & 0.416 \\
\hline \multicolumn{6}{|l|}{ Outputs } \\
\hline Primary school completion rate & 360 & 7.860 & 75.650 & 35.317 & 13.616 \\
\hline Gross school attendance rate & 360 & 21.550 & 102.670 & 63.592 & 17.333 \\
\hline
\end{tabular}

Table 1 Descriptive statistics

Examination of these descriptive statistics reveals that the standard deviations of the outputs are greater than those of the inputs. This reveals that inter-provincial disparities in the results obtained exceed differences in resource allocation.

\section{$6 \quad$ Inefficiency in Burkinabe educational system}

In this section we present and analyse the results of the study on Burkinabe education system efficiency. Efficiency scores corrected for bias were obtained using

\footnotetext{
${ }^{6}$ We here use an approximation to all the equipment used in primary education, to wit, tables, chairs, benches, blackboards, etc.

${ }^{7}$ In Burkina Faso the ministry of education supplies the pupils with some educational supplies, such as textbooks and copybooks, in order to promote access to primary education.
} 
the method proposed by Simar and Wilson (1998). For these purposes, 5,000 simulated samples were created and the CCR model was solved for each of these samples. Comparing the bias and variance for each DMU considered, ${ }^{8}$ according to the method in Equation (6), confirmed the validity of the corrected efficiency scores. Therefore, we use these corrected efficiency scores in all of our analyses. Furthermore, in the output-oriented DEA the efficiency score attributed to each DMU expresses the factor by which its outputs must be multiplied for it to be considered efficient with regard to its reference set. Therefore, the higher this score, the less efficient the DMU. Table 2 presents descriptive statistics for the efficiency results of primary education in Burkina Faso.

\begin{tabular}{lrrrrr}
\hline & $\begin{array}{c}\text { Number of } \\
\text { DMUs }\end{array}$ & Minimum & Maximum & Mean & $\begin{array}{c}\text { Standard } \\
\text { deviation }\end{array}$ \\
\hline Efficiency scores & 360 & 1.00 & 3.27 & 1.53 & 0.430 \\
Corrected efficiency scores & 360 & 1.07 & 3.57 & 1.67 & 0.461 \\
Bias & 360 & -0.39 & -0.04 & -0.14 & 0.063 \\
\hline
\end{tabular}

Table 2 Descriptive statistics for the efficiency results

These results demonstrate a high average level of inefficiency in the Burkinabe education system, with an inefficiency score near 1.70. This also reveals that, for the level of inputs used, a number of decision-making units would need to increase their output substantially to be as efficient as the most productive DMUs in the sample. The outputs of primary education could have increased by about $70 \%$ if all the DMU were quite perfectly efficient. Moreover, we find some differences between the provinces. Figure 1 presents the mean level of inefficiency in each of the 45 provinces of Burkina Faso.

\footnotetext{
${ }^{8}$ Here a DMU represents an observation on one province at one point in time.
} 


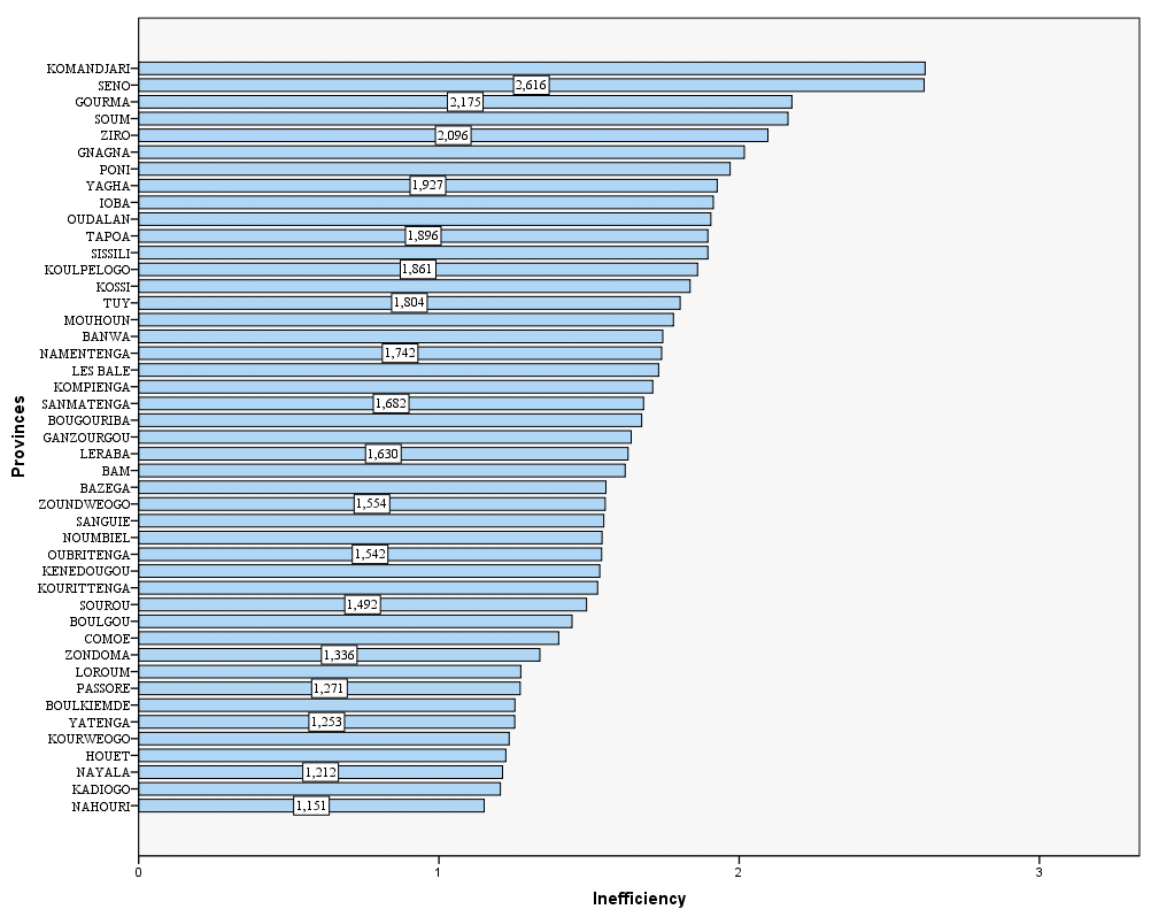

Figure 1 : Mean inefficiency level in each province

We observe that mean inefficiency varies considerably from one province to the next. At 2.61, the highest level of inefficiency is recorded in the province of Komandjari, while the lowest level identified is 1.15, in the province of Nahouri. Moreover, the most inefficient DMU is the province of Komandjari (2011), while the least inefficient DMU is the province of Nahouri (2008). In addition, Figure 2 reveals that trends in mean inefficiency over time are not monotonic. 


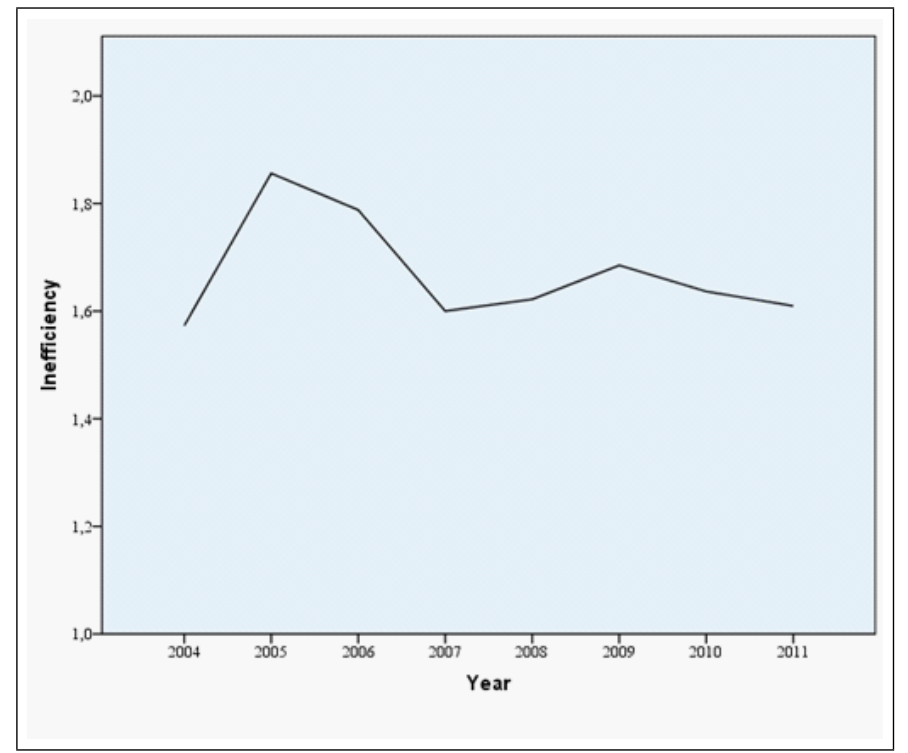

Figure 2 : Trends in mean ineficiency over time

We note that overall inefficiency appears to have risen between 2004 and 2005, then declined before resuming its upward trend after 2007. We believe that the decline in inefficiency between 2006 and 2007 could be associated with a crisis in the PDDEB in 2005 and a concomitant reduction in the provision of infrastructure, human resources, and materials ${ }^{9}$. With outputs remaining constant (even more increasing), this reduction automatically caused a decline in inefficiency. We also detect that, between 2007 and 2009, inefficiency level is almost identical. An analysis of inefficiency extending over a relatively long period after the end of the PDDEB would undoubtedly reveal an important decrease of inefficiency. The underlying notion is that the two outputs need some time to adjust after an increase in inputs. As a result, in the short term inefficiency may appear to increase following a massive injection of inputs, but this effect should tend to dissipate over time, as DMUs adjust. The findings also reveal that returns to scale are decreasing in nearly $73 \%$ of provinces, so allocating more inputs to basic education does not appear sufficient for improving efficiency. The fact that Kadiogo ${ }^{10}$ is one of the least inefficient provinces raises a fundamental question. In light of the fact that the population of this province is the least poor in the country ${ }^{11}$, we might be inclined to speculate that there's a relationship between living situations and inefficiency in the management of educational resources. We are primarily interested in whether inefficiency in the education system is attributable to difficulties in households living situations. In addition, it is possible that some elements inherent in the

\footnotetext{
${ }^{9}$ http://www.lefaso.net/spip.php? article11110

${ }^{10}$ This province includes Ouagadougou, the capital of Burkina Faso.

${ }^{11}$ In 2003 this province posted the lowest incidence of poverty.
} 
educational system contribute to making decision units more or less inefficient. The following section seeks to establish a causal link between inefficiency and the living situations of Burkinabe households.

\section{Inefficiency in education and households' liv- ing situations}

Households' quality of life may play a role in explaining attendance and success in postsecondary studies. In fact, in the light of several studies performed in Western countries, such as Canada, the notion that parents' standard of living affects access to education and success in school has gained widespread acceptance. This link will become all the more evident if we consider that, for example, a pupil in a developing country may suffer from malnutrition and the unavailability of healthcare. In this regard, in a study of five African countries (including Burkina Faso), Michaelowa (2000) finds that the poorest children are disadvantaged in the area of school achievements. She attributes this to the fact that some key elements of learning for children, such as the availability of books, literacy of the parents, access to media, the possibility of studying at home, and regular meals, are related to their families' standard of living. Balma et al. (2010) find that the poorest Burkinabe families are only half as likely to enroll their children in primary school. This suggests that the living conditions of Burkinabe households may have an impact on the "quantity" and "quality" of primary education. In this section, we attempt to establish a causal link between households' living conditions and inefficiency in the primary education system. To do this, as we explain above, we perform an econometric regression based on the Simar and Wilson (2007) double bootstrap procedure Table 3 presents descriptive statistics for the variables used to assess households' living conditions. 


\begin{tabular}{|c|c|c|c|c|c|}
\hline & Observation & Minimum & Maximum & Mean & $\begin{array}{c}\text { Std. } \\
\text { Deviation }\end{array}$ \\
\hline $\begin{array}{l}\text { Households with housing walls in } \\
\text { cement (in \%) }\end{array}$ & 135 & 0.10 & 60.40 & 8.14 & 9.36 \\
\hline $\begin{array}{l}\text { Households with housing roof in } \\
\text { sheet steel }(\%)\end{array}$ & 135 & 2.90 & 94.80 & 38.17 & 17.90 \\
\hline $\begin{array}{l}\text { Households using electricity as } \\
\text { main mode of lighting }(\%)\end{array}$ & 135 & 0.00 & 55.10 & 7.18 & 8.58 \\
\hline $\begin{array}{l}\text { Households with access to a } \\
\text { primary school in less than } 30 \\
\text { minutes }(\%)\end{array}$ & 135 & 28.40 & 93.70 & 61.66 & 15.30 \\
\hline $\begin{array}{l}\text { Households with access to a } \\
\text { secondary school in less than } \mathbf{3 0} \\
\text { minutes (\%) }\end{array}$ & 135 & 3.60 & 71.60 & 17.41 & 11.99 \\
\hline $\begin{array}{l}\text { Households with access to a } \\
\text { healthcare center in less than } 30 \\
\text { minutes }(\%)\end{array}$ & 135 & 5.70 & 82.10 & 31.90 & 13.564 \\
\hline $\begin{array}{l}\text { Households with access to a } \\
\text { market in less than } 30 \text { minutes } \\
(\%)\end{array}$ & 135 & 18.90 & 86.40 & 50.77 & 17.19 \\
\hline $\begin{array}{l}\text { Private classrooms in household } \\
\text { environment }(\%)\end{array}$ & 135 & 0.00 & 52.28 & 8.61 & 8.70 \\
\hline
\end{tabular}

Table 3 Descriptive statistics of households' living conditions

Table 4 shows results from OLS, Tobit and Simar and Wilson (2007) estimations in order to compare Simar and Wilson algorithm with others techniques commonly used ${ }^{12}$. Only three of the variables we considered in this analysis have a significative impact on inefficiency. Thus, access to electricity seems to have a negative impact on inefficiency. In other word, using electricity as main mode of lighting improves primary education efficiency. As in Burkina Faso, most of the population have no access to electricity, such an access can be considered as an indicator of higher standard of living. Furthermore, inefficiency seems to decrease with the nearness to a healthcare center. We can easily suppose that access to healthcare allows students to remain healthy and then more productive in classrooms. This contributes to improve primary education quality. Finally, the proximity to secondary schools seems to improve primary education efficiency. High school students certainly participate to share benefits of education in households and to support primary school students in their studies. Thus, the nearness to high school students should improve access to and quality of primary education and then reduce inefficiency.

\footnotetext{
${ }^{12}$ Apart from the variable "access to electricity" the signs of the coefficients are the same in all models.
} 


\begin{tabular}{|c|c|c|c|}
\hline & OLS & Tobit & $\begin{array}{c}\text { Simar and } \\
\text { Wilson (2007) }\end{array}$ \\
\hline $\begin{array}{l}\text { Households with housing walls in } \\
\text { cement (in \%) }\end{array}$ & $\begin{array}{c}0,006 \\
(0,010)\end{array}$ & $\begin{array}{c}0,007 \\
(0,011)\end{array}$ & $\begin{array}{c}0,024 \\
(0,008)\end{array}$ \\
\hline $\begin{array}{l}\text { Households with housing roof in sheet } \\
\text { steel }(\%)\end{array}$ & $\begin{array}{c}0,003 \\
(0,004)\end{array}$ & $\begin{array}{c}0,004 \\
(0,004)\end{array}$ & $\begin{array}{c}0,005 \\
(0,021)\end{array}$ \\
\hline $\begin{array}{l}\text { Households using electricity as main } \\
\text { mode of lighting }(\%)\end{array}$ & $\begin{array}{l}0,021^{*} \\
(0,011)\end{array}$ & $\begin{array}{l}0,020^{*} \\
(0,012)\end{array}$ & $\begin{array}{l}-0,012 * * * \\
(0,005)\end{array}$ \\
\hline $\begin{array}{l}\text { Households with access to a primary } \\
\text { school in less than } 30 \text { minutes }(\%)\end{array}$ & $\begin{array}{c}0,019 \\
(0,013)\end{array}$ & $\begin{array}{c}0,001 \\
(0,003)\end{array}$ & $\begin{array}{c}0,001 \\
(0,004)\end{array}$ \\
\hline $\begin{array}{l}\text { Households with access to a } \\
\text { secondary school in less than } 30 \\
\text { minutes }(\%)\end{array}$ & $\begin{array}{c}-0,016^{* *} \\
(0,009)\end{array}$ & $\begin{array}{c}-0,021 * * \\
(0,010)\end{array}$ & $\begin{array}{c}-0,016^{* *} \\
(0,011)\end{array}$ \\
\hline $\begin{array}{l}\text { Households with access to a } \\
\text { healthcare center in less than } 30 \\
\text { minutes }(\%)\end{array}$ & $\begin{array}{c}-0,014 * * \\
(0,007)\end{array}$ & $\begin{array}{c}-0,015 * * \\
(0,007)\end{array}$ & $\begin{array}{l}-0,020 * * * \\
(0,005)\end{array}$ \\
\hline $\begin{array}{l}\text { Households with access to a market in } \\
\text { less than } 30 \text { minutes }(\%)\end{array}$ & $\begin{array}{c}0,008 * * * \\
(0,004)\end{array}$ & $\begin{array}{c}0,009 \\
(0,004)\end{array}$ & $\begin{array}{c}0,010 \\
(0,034)\end{array}$ \\
\hline $\begin{array}{l}\text { Private classrooms in household } \\
\text { environment }(\%)\end{array}$ & $\begin{array}{c}-0,014 * * \\
(0,006)\end{array}$ & $\begin{array}{c}-0,017 * * \\
(0,007)\end{array}$ & $\begin{array}{l}-0,005 \\
(0,005)\end{array}$ \\
\hline Intercept & $\begin{array}{c}1,534 * * * \\
(0,159)\end{array}$ & $\begin{array}{c}1,473 * * * \\
(0,177)\end{array}$ & \\
\hline \multirow[t]{2}{*}{ Time variables } & Yes & Yes & Yes \\
\hline & $\begin{array}{c}\text { R-squared }= \\
0.2889 \\
\text { Prob }>\mathrm{F}= \\
0.0000\end{array}$ & $\begin{array}{c}\text { Pseudo R2 }= \\
0.2760 \\
\text { Prob }>\mathrm{F}= \\
0.0000\end{array}$ & \\
\hline
\end{tabular}

Table 4 Second stage regressions

\section{Conclusion}

In this study we use data envelopment analysis to measure the efficiency with which primary education is provided in the 45 provinces of Burkina Faso. More precisely, we measure the efficiency with which resources allocated to primary education are transformed into "quantity" and "quality" of education in that country. We find that, overall, the level of inefficiency is pretty high. There appears to have been an increase in inefficiency during the period covered by the study, primarily because of the sluggishness with which outputs were able to adjust to an influx of investment into primary education from large-scale basic education development projects, in particular the PDDEB. Moreover, in nearly $73 \%$ of the provinces evaluated, returns to scale in basic education are decreasing. Also, we were able to establish a relationship between inefficiency and standard of living, and found that access to electricity, being close to a 
healthcare center or to a secondary school have a positive effect on efficiency. Contingent on data availability, more targeted studies could examine the causal link between efficiency in primary education in Burkina Faso and others variables related to poverty.

\section{References}

[1] Afonso, A. and St. Aubyn, M. 2006. Cross-country efficiency of secondary education provision: A semi-parametric analysis with non-discretionary inputs. Economic Modelling. 23(3). 476-491.

[2] Alexander ,W., Haug, A. and Jaforullah, M. 2010. A two-stage doublebootstrap data envelopment analysis of efficiency differences of New Zealand secondary schools. Journal of Productivity Analysis. 34(2). 99-110.

[3] Balma, L., Ilboudo, A. F. W., Ouattara, A., Kaboré, R. Zerbo, K. and Kaboré, T.S., 2010. Dépenses publiques d'éducation et pauvreté au Burkina Faso. MPIA4.

[4] Banker, R.D., R.F. Charnes, and W.W. Cooper, 1984. Some models for estimating technical and scale inefficiencies in Data Envelopment Analysis. Management Science. 30. 1078-1092.

[5] Barrow, M. H., 1991. Measuring local education authority performance: a frontier approach. Economics of Education Review, 10, 19-27.

[6] Bates, J. M., 1997. Measuring predetermined socioeconomic 'inputs' when assessing the efficiency of educational outputs. Applied Economics. 29. 8593.

[7] Becker, G.S., 1964. Human capital. A theoretical and empirical analysis with special reference to education, New York : Columbia University Press.

[8] Bessent, A., Bessent, W., Kennington, J. and Reagan, B., 1982. An application of mathematical programming to assess productivity in the Houston independent school district. Management Science., 28. 1355- 1367.

[9] Bourdon J., 2009. La mesure de l'efficacité scolaire par la méthode de l'enveloppe : test des filières alternatives de recrutement des enseignants dans le cadre du processus Éducation pour tous, 26th Journées de Microéconomie appliquée, 2009, Dijon, France

[10] Burkhead, J., 1967. Inputs and outputs in large city High Schools. Syracuse : Syracuse University Press.

[11] Chalos, P., 1997. An examination of budgetary inefficiency in education using data envelopment analysis, Financial Accountability and Management, $13,55-69$. 
[12] Charnes A., W.W. Cooper and E. Rhodes, 1978. Measuring the efficiency of decision making units. European Journal of Operational Research. 2. 429-444.

[13] Cooper W.W., L.M. Seiford and K Tone, 2007. Data Envelopment Analysis: A comprehensive text with models, applications, references and DEASolver software. Second edition. 490p.

[14] Correa, H., 1963. The economics of human resources, Amsterdam, NorthHolland. Deller, S. C. and Rudnicki, E. R., 1993. Production efficiency in elementary education: the case of Maine public schools, Economics of Education Review, 12, 45-57.

[15] Denison, E.F, 1962. The sources of economic growth in the United States and the alternative before us. New York: Committee for Economic Development.

[16] Duncombe. W., Miner, J. and Ruggiero, J., 1997. Empirical evaluation of bureaucratic models of inefficiency, Public Choice, 93, 1-18.

[17] Engert, F., 1996. The reporting of school district efficiency: the adequacy of ratio measures, Public Budgeting and Financial Management, 8, 247-271.

[18] Färe, R., Grosskopf, S. and Weber, W., 1989. Measuring school district performance, Public Finance Quarterly, 17, 409- 428.

[19] Farrell, M. J., 1957. The measurement of productive efficiency. Journal Of The Royal Statistical Society. 120. Part III. 253-281.

[20] Gui-hong, S., 2010. Technical efficiency of corn production in main producing region in China based on DEA-Tobit. Asian Agricultural Research. 2(12). 5-11.

[21] Johnes, J., 2003. Measuring the efficiency of universities: A comparison of multilevel modelling and Data Envelopment Analysis, Lancaster University Management School Working Paper 2003/082.

[22] Kumar, S. and Gulati, R., 2009. Technical efficiency and its determinants in the Indian domestic banking industry: an application of DEA and Tobit analysis, American Journal of Finance and Accounting. 1(3). 256-296.

[23] Marschall, P. and Flessa, S., 2011. Assessing the efficiency of rural health centres in Burkina Faso: an application of Data Envelopment Analysis. Journal of public Health. 17(2). 87-95.

[24] Michaelowa, K., 2000. Dépenses d'éducation, qualité de l'éducation et pauvreté : l'exemple de cinq pays d'Afrique francophone. Centre de développement de l'OCDE Document de travail No. 157. 
[25] Michaud, P., 1981. La mesure de la productivité dans le domaine de l'éducation : un examen des écrits. Revue des sciences de l'éducation. 7(3). 487-502.

[26] Ministère de l'économie et des finances, 2004. Cadre Stratégique de Lutte contre la Pauvreté. Gouvernement du Burkina Faso.

[27] Parteka, A. and Wolszczak-Derlacz, J. 2011. Dynamics of productivity in higher education. Cross-European evidence based on bootstrapped Malmquist indices.Departmental Working Papers 2011-10, Department of Economics, Management and Quantitative Methods at Università degli Studi di Milano.

[28] Puig-Junoy, J., 1998. Technical efficiency in the clinical management of critically ill patients. Health Economics. 7. 263-277.

[29] Ray, S.C., 1991. Resource-use efficiency in public schools: a study of Connecticut data. Management Science. 37. 1620-1628.

[30] Ruggiero, J., 1996. On the measurement of technical efficiency in the public sector, European Journal of Operational Research, 90, 553-565.

[31] Schultz, T.W., 1961. Investment in human capital. American Economic Review. 51. 1-17. Sexton, T.R., S. Sleeper and R.E. Taggart Jr, 1994. Improving pupil transportation in North Carolina. Interfaces 24, 87-103.

[32] Simar, L. and P.W. Wilson, 1998. Sensitivity analysis of efficiency scores: How to bootstrap in nonparametric frontier models, Management Science, 44, 49-61.

[33] Simar, L. and Wilson, P. W., 2007. Estimation and inference in two-stage, semiparametric models of production processes. Journal of Econometrics, 136(1), 31-64.

[34] Stanton, K.R., 2002. Trends in relationship lending and factors affecting relationship lending efficiency. Journal of Banking and Finance. 26. 127152.

[35] Thanassoulis, E. and Dunstan, P., 1994. Guiding schools to improved performance using data envelopment analysis: an illustration with data from a local education authority, Journal of the Operational Research Society, 45, 1247- 1262 .

[36] Worthington, A. C., 2001. An empirical survey of frontier efficiency measurement techniques in education. Education Economics, 9(3), 245-245.

[37] Wouterse, F., 2011. Social services, human capital, and technical efficiency of smallholders in Burkina Faso. IFPRI Discussion Paper 01068. 